\title{
Novel insights into the mechanisms mediating the local antihypertrophic effects of cardiac atrial natriuretic peptide: role of cGMP-dependent protein kinase and RGS2
}

\author{
Michael Klaiber • Martin Kruse • Katharina Völker · Juliane Schröter • Robert Feil • Marc Freichel • \\ Andrea Gerling • Susanne Feil • Alexander Dietrich • Juan Eduardo Camacho Londoño • Hideo A. Baba • \\ Joel Abramowitz $\cdot$ Lutz Birnbaumer · Josef M. Penninger • Olaf Pongs • Michaela Kuhn
}

Received: 21 December 2009/Revised: 17 February 2010/Accepted: 16 March 2010/Published online: 30 March 2010

(C) The Author(s) 2010

\begin{abstract}
Cardiac atrial natriuretic peptide (ANP) locally counteracts cardiac hypertrophy via the guanylyl cyclase-A (GC-A) receptor and cGMP production, but the downstream signalling pathways are unknown. Here, we examined the influence of ANP on $\beta$-adrenergic versus Angiotensin II (Ang II)-dependent $\left(\mathrm{G}_{\mathrm{s}}\right.$ vs. $\mathrm{G}_{\alpha \mathrm{q}}$ mediated) modulation of $\mathrm{Ca}^{2+}{ }_{\mathrm{i}}$-handling in cardiomyocytes and of hypertrophy in intact hearts. L-type $\mathrm{Ca}^{2+}$ currents and $\mathrm{Ca}^{2+}{ }_{\mathrm{i}}$ transients in adult isolated murine ventricular myocytes were studied by voltage-clamp recordings and fluorescence microscopy. ANP suppressed Ang II-stimulated $\mathrm{Ca}^{2+}$ currents and transients, but had no effect on isoproterenol stimulation. Ang II suppression by ANP was abolished in cardiomyocytes of mice deficient in GC-A, in cyclic GMP-dependent protein kinase I (PKG I) or in the
\end{abstract}

M. Klaiber · K. Völker · J. Schröter · M. Kuhn $(\square)$

Institute of Physiology, University of Würzburg,

Physiologisches Institut der Universität Würzburg,

Röntgenring 9, 97070 Würzburg, Germany

e-mail: michaela.kuhn@mail.uni-wuerzburg.de

M. Kruse · O. Pongs

Institut für Neurale Signalverarbeitung,

Zentrum für Molekulare Neurobiologie,

Universität Hamburg, Hamburg, Germany

R. Feil · A. Gerling $\cdot$ S. Feil

Interfakultäres Institut für Biochemie,

Universität Tübingen, Tübingen, Germany

M. Freichel - J. E. C. Londoño

Experimentelle und Klinische Pharmakologie und Toxikologie,

Universität des Saarlandes, Homburg, Germany

A. Dietrich

Institut für Pharmakologie und Toxikologie,

Philipps-Universität Marburg, Marburg, Germany regulator of G protein signalling (RGS) 2, a target of PKG I. Cardiac hypertrophy in response to exogenous Ang II was significantly exacerbated in mice with conditional, cardiomyocyte-restricted GC-A deletion (CM GC-A KO). This was concomitant to increased activation of the $\mathrm{Ca}^{2+}$ / calmodulin-dependent prohypertrophic signal transducer CaMKII. In contrast, $\beta$-adrenoreceptor-induced hypertrophy was not enhanced in CM GC-A KO mice. Lastly, while the stimulatory effects of Ang II on $\mathrm{Ca}^{2+}$-handling were absent in myocytes of mice deficient in TRPC $3 /$ TRPC6, the effects of isoproterenol were unchanged. Our data demonstrate a direct myocardial role for ANP/GC-A/ cGMP to antagonize the $\mathrm{Ca}^{2+}{ }_{\mathrm{i}}$-dependent hypertrophic growth response to Ang II, but not to $\beta$-adrenergic stimulation. The selectivity of this interaction is determined by

H. A. Baba

Institute of Pathology, University Hospital of Essen,

University of Duisburg-Essen, Essen, Germany

J. Abramowitz · L. Birnbaumer

Laboratory of Neurobiology,

National Institute of Environmental Health Sciences,

National Institutes of Health, Research Triangle Park,

NC, USA

J. M. Penninger

IMBA, Institute of Molecular Biotechnology of the Austrian Academy of Sciences, Vienna, Austria 
PKG I and RGS2-dependent modulation of Ang II/AT signalling. Furthermore, they strengthen published observations in neonatal cardiomyocytes showing that TRPC3/ TRPC6 channels are essential for Ang II, but not for $\beta$-adrenergic $\mathrm{Ca}^{2+}{ }_{\mathrm{i}}$-stimulation in adult myocytes.

Keywords ANP · Angiotensin II - cGMP-dependent protein kinase $\cdot$ RGS2 Cardiac hypertrophy

\section{Introduction}

Cardiac atrial natriuretic peptide (ANP) lowers arterial blood pressure and intravascular volume by a combination of direct and indirect effects that involve vasodilatation, increases in endothelial permeability, stimulation of renal function, and inhibition of the sympathetic as well as renin-angiotensinaldosterone (RAA) systems [25, 26]. These actions of ANP are mediated by a membrane-bound guanylyl cyclase (GC) receptor, GC-A, which mediates increases in intracellular cyclic GMP levels in response to ANP binding [25, 26]. Mice with global disruption of the GC-A gene (GC-A-/- mice) not only have increased systemic arterial blood pressure but also display a marked cardiac hypertrophy which is disproportionate to their increased blood pressure and partly resistant to antihypertensive medication [23, 28]. Extending these studies, our own observations in mice with conditional, cardiomyocyte-restricted deletion of GC-A (CM GC-A KO mice) demonstrated that ANP, via GC-A/cGMP signalling, exerts important local, auto/paracrine functions to moderate pathological cardiomyocyte growth [18]. The intracellular signalling pathways mediating the local antihypertrophic effects of ANP/GC-A are unknown. Because patients with essential hypertension and/or cardiac hypertrophy/insufficiency exhibit diminished systemic and cardiac responsiveness to ANP [25, 26], clarification of this issue is important from a physiological and also pathophysiological perspective.

On the opposite, the RAA system enhances arterial blood pressure and volume. Angiotensin II (Ang II) is a potent vasoconstrictor, it increases sympathetic tone and exerts indirect antidiuretic and antinatriuretic actions via stimulation of aldosterone and antidiuretic hormone (ADH) secretion [21]. Besides these systemic actions, locally produced Ang II exerts direct trophic actions within the heart, inducing cardiomyocyte hypertrophy, fibroblast proliferation and interstitial fibrosis, thereby contributing to pathologic cardiac remodelling $[4,32,40]$. Both the hypertensive and cardiac hypertrophic as well as profibrotic actions of Ang II are mediated through the Ang II type $1\left(\mathrm{AT}_{1}\right)$ receptor $[4,37,39]$.

Importantly, ANP counter regulates not only the systemic but also the cardiac effects of the RAA system. It inhibits renin release and Ang II-stimulated aldosterone production [29, 31] and antagonizes the vasoconstrictor, sympathotonic, and antinatriuretic actions of Ang II [22], but also inhibits trophic effects of Ang II on cultured cardiac myocytes and fibroblasts [9]. Thus, the physiological balance between the ANP/GC-A and Ang II/AT ${ }_{1}$ systems is not only involved in the endocrine maintenance of arterial blood pressure and intravascular volume homeostasis, but also in the local, paracrine regulation of cardiac growth.

Cardiac myocytes respond to increased mechanical work-load or to neurohumoral stressors, such as Ang II by altering the frequency and amplitude of their calcium transients $[1,8,16]$. Encoded in these calcium responses are signals that, at difference to $\beta$-adrenergic stimulation, alter not only immediate contractility, but also initiate and maintain a remodelling response that adjusts cellular mass, ionic currents, kinetic properties of contractile proteins, and metabolic capacity [16]. Persistence of these signals modulates the calcium signalling events resulting in a hypertrophic response and adverse remodelling. Recent work indicates that hypertrophic agonists linked to $\mathrm{G} \alpha \mathrm{q}-$ protein coupled receptors such as Ang II activate calcium entry through transient receptor potential canonical (TRPC) channels [34] and that these channels, especially TRPC1, C3 and C6, can trigger pathologic, hypertrophic calcium signalling in the heart $[34,41]$. In contrast, physiological (e.g. exercise-induced) or $\beta$-adrenergic modulation of myocyte calcium and growth apparently does not involve TRPC channels. However, this hypothesis is mostly based on the work with cultured neonatal rat myocytes [34], which exhibit important structural, biochemical and functional differences to adult cardiac myocytes.

To gain new insights into the intracellular signalling pathways mediating the local antihypertrophic effects of ANP/GC-A, we compared the influence of ANP on $\beta$-adrenergic versus Ang II-dependent $\left(\mathrm{G}_{\mathrm{s}}\right.$ vs. $\mathrm{G}_{\alpha \mathrm{q}}$ mediated) modulation of $\mathrm{Ca}^{2+}{ }_{\mathrm{i}}$ handling in cardiomyocytes and of cardiac hypertrophy in mice. The results demonstrate the role and functional compartmentation of cGMP and cGMPdependent protein kinase type I (PKG I) stimulation by ANP in the heart. They also emphasize that TRPC3/TRPC6 channels are essential for the increase of $\left[\mathrm{Ca}^{2+}\right]_{i}$ in adult myocytes by Ang II, but not by isoprenaline.

\section{Materials and methods}

Genetic mouse models

Mice with conditional, cardiomyocyte-restricted deletion of the GC-A receptor (CM GC-A KO mice) and control 
littermates (floxed GC-A mice, with normal GC-A expression levels) were generated and genotyped as described [18]. Transgenic mice with genetic deletion of PKG I [49], regulator of G protein signalling (RGS)-2 [15] or TRPC3/C6 channels and respective control mice were obtained from collaborating laboratories. The PKG I mutants were so-called SM-I $\beta$ rescue mice [49]. These mice carry the SM-I $\beta$ transgene that restores expression of the PKG I $\beta$ isozyme selectively in smooth muscle cells, but not in other cell types of PKG I null mice (genotype PKG $\left.\mathrm{I}^{\mathrm{L}-/ \mathrm{L}-} ; \mathrm{SM}-\mathrm{I} \beta^{+/-}\right)$. As controls, litter- and gender-matched mice expressing endogenous PKG I and the SM-I $\beta$ transgene were used (genotype PKG I ${ }^{+/ L-}$; SM-I $\beta^{+/-}$). TRPC3/ TRPC6 $^{-/-}$were generated by crossing the TRPC ${ }^{-/-}$[11] and TRPC6 ${ }^{-1-}$ [3] mouse lines. All investigations conform with the guidelines for the care and use of laboratory animals (National Institutes of Health, Publication No 85-23, revised 1996) and were approved by the local animal care committee.

Measurement of cardiomyocyte $\mathrm{Ca}^{2+}{ }_{\mathrm{i}}$ transients and single-cell contractility

Adult ventricular myocytes were isolated by liberase/ trypsin digestion [for Procedure see Protocol PP00000125 from The Alliance for Cellular Signalling (AfCS)]. Wholecell $\mathrm{Ca}^{2+}{ }_{\mathrm{i}}$ transients together with simultaneously recorded cell length were measured in INDO-1 loaded, electrically paced $(0.5 \mathrm{~Hz})$ cardiomyocytes as described before [20]. Excitation was at $365 \mathrm{~nm}$, and the emitted fluorescence was recorded at 405 and $495 \mathrm{~nm}$. The ratio of fluorescence at the two wavelengths was used as an index of the cytosolic $\mathrm{Ca}^{2+}$ concentration. Data were collected at $20 \mathrm{~Hz}$, and acquisition and processing were supported by Felix software (Felix version 1.1, Photon Technologies, Seefeld, Germany) [20]. After obtaining basal recordings for $10 \mathrm{~min}$, myocytes were exposed to Ang II (10 $\mathrm{nM})$ or isoproterenol (ISO, $100 \mathrm{nM}$; both Sigma, Taufkirchen, Germany) in the presence or absence of ANP (mouse ANP, $100 \mathrm{nM}$; Bachem, Heidelberg, Germany) (superfusion of cardiomyocytes with ANP or vehicle during $10 \mathrm{~min}$; then superfusion with Ang II or ISO in the presence of ANP during additional $10 \mathrm{~min}$ ).

Electrophysiological recordings on ventricular myocytes

Single cardiomyocytes were studied using the whole-cell configuration of the patch-clamp technique [24]. For recordings, cells were plated in a small dish $(2 \mathrm{~cm} \emptyset)$ on the stage of an inverted microscope (Leica, Cologne, Germany) directly before the start of the measurements. For voltage-clamp recordings of L-type $\mathrm{Ca}^{2+}$ channel activity the extracellular solution was composed of (mM): $\mathrm{NaCl}$ 135.0, $\mathrm{MgCl}_{2}$ 0.53, $\mathrm{Na}_{2} \mathrm{HPO}_{4}$ 0.33, HEPES 5.0, glucose $5.5, \mathrm{CaCl}_{2} 1.8$, adjusted to $\mathrm{pH} 7.4$ with $\mathrm{NaOH}$. The micropipette electrodes (resistances 2.0-3.5 M $\Omega$ ) were filled with (mM): $\mathrm{CsCl}$ 120.0, EGTA 10.0, $\mathrm{MgCl}_{2}$ 1.0, MgATP 4.0, HEPES 5.0, adjusted to $\mathrm{pH} 7.2$ with $\mathrm{CsOH}$. Holding potential was $-90 \mathrm{mV}$. Currents were elicited by a first voltage step to $-50 \mathrm{mV}$ for $70 \mathrm{~ms}$ to evoke $\mathrm{Na}_{\mathrm{V}^{-}}$ channel activity followed by a depolarization to $0 \mathrm{mV}$ for $600 \mathrm{~ms}$ to activate L-type $\mathrm{Ca}^{2+}$ channel-mediated current. For current-clamp recordings, bath solution was composed of (mM): $\mathrm{NaCl} 143.0, \mathrm{Na}_{2} \mathrm{HPO}_{4}$ 0.25, $\mathrm{KCl} 5.4, \mathrm{CaCl}_{2}$ 1.8, $\mathrm{MgCl}_{2}$ 0.5, glucose 5.6, HEPES 5.0, adjusted to $\mathrm{pH} 7.35$ with $\mathrm{NaOH}$. Pipette solution for these recordings was composed of (mM): $\mathrm{KCl} 125.0, \mathrm{CaCl}_{2} 1.0, \mathrm{MgCl}_{2}$ 1.0, EGTA 11.0, HEPES 10.0, sucrose 10.0, adjusted to $\mathrm{pH} 7.2$ with $\mathrm{KOH}$. All experiments were done at room temperature. Recordings were performed with an EPC9 PatchClamp amplifier (HEKA, Lambrecht, Germany) and analyzed with PulseFIT software (HEKA, Lambrecht, Germany) [24].

Effect of ANP/PKG I on expression and subcellular localization of RGS2 in HEK 293 cells

Human embryonic kidney (HEK)-293 cells stably expressing GC-A were transiently cotransfected with cDNAs coding for human regulator of $G$ protein signalling (RGS) 2 and PKG I $\alpha$ using FuGENE reagent according to manufacturer's instructions (Roche, Mannheim, Germany). After 2 days of transfection, the cells were treated with ANP (10 nM) or vehicle for the indicated time. For separation of the cytosolic, membrane, and nuclear proteins, a cell fractionation kit was applied (nano-TOOLS Antikörpertechnik, Teningen, Germany). SDS-PAGE and immunoblotting were performed as previously described [12]. Antibodies were against GC-A [12], PKG I [48], RGS2 (ProteinTech Group, Chicago, USA) and GAPDH. The blots were developed using the ECL detection system (Amersham-Pharmacia, Freiburg, Germany) and the results were quantitated by densitometry (ImageQuant) [12, 20].

\section{Chronic treatment of mice with Ang II or ISO}

Control and CM GC-A KO mice were infused subcutaneously with vehicle, Ang II (250 ng/kg BW/min, 2 weeks) or ISO (40 mg/kg BW/day, 7 days [5]) via osmotic minipumps (model 2002; Alzet, Colorado City, CO). Male and female mice 4-6 weeks old were examined $(n=8-12$ mice per group). Arterial blood pressure was measured in conscious mice of the three treatment groups by tail cuff (Softron, Tokyo, Japan) [18, 20]. Mice were then killed under urethane anesthesia, the hearts were weighed and the 
left ventricles were bisected and frozen in liquid nitrogen (for protein extraction) and fixed in $4 \%$ buffered formaldehyde (for histology).

\section{Histology}

For histological analysis, formaldehyde-fixed left ventricles were embedded in paraffin, and $5-\mu \mathrm{m}$ sections were stained with hematoxylin eosin or periodic acid Schiff (PAS, to discriminate cardiomyocyte cell borders) [18, 20]. Photomicrographs of the sections were evaluated using the computer-assisted image analysis system Cell-D (Olympus, Hamburg Germany), with the investigator blinded to the genotypes. The mean cross-sectional cardiomyocyte diameters were calculated by measuring 100 cells with a centrally located nucleus per specimen.

\section{Western-blot analyses}

Left ventricular proteins were solubilized in SDS-sample buffer and separated by 10\% PAGE. The primary antibodies were against CaMKII (BD Transduction Laboratories) and autophosphorylated (active) CaMKII (Santa Cruz). GAPDH was used to control equal loading. The blots were developed using the ECL detection system and the results were quantitated by densitometry.

\section{Statistics}

The results are presented as mean \pm SEM. Group data were compared using one-way or two-way ANOVA (with genotype and treatment as categories) followed by the multiple comparison Bonferroni $t$ test to assess differences between groups. The significance level was set at $P<0.05$.

\section{Results}

ANP inhibits the $\mathrm{Ca}^{2+}$ responses of adult mouse cardiac myocytes to Ang II, but not to ISO

Single-cell fluorescence imaging of $\mathrm{Ca}^{2+}{ }_{\mathrm{i}}$ transients in Indo-1AM loaded ventricular myocytes showed that both Ang II $(10 \mathrm{nM})$ and ISO $(100 \mathrm{nM})$ led to prompt and marked increases in systolic $\mathrm{Ca}^{2+}{ }_{\mathrm{i}}$ levels and thereby in the amplitude of $\mathrm{Ca}^{2+}{ }_{\mathrm{i}}$ transients (Fig. 1a, b). The responses were accompanied by increased sarcomere shortening (Fig. 1c, d). The exposure of isolated myocytes to $100 \mathrm{nM}$ ANP did not change the resting $\mathrm{Ca}^{2+}{ }_{\mathrm{i}}$ transient or basal sarcomere shortening (Fig. 1a-d). However, ANP had very different effects on the responses to ISO and Ang II. Calcium and shortening responses to Ang II were totally prevented by ANP $(100 \mathrm{nM}, 10-\mathrm{min}$ pretreatment
(Fig. 1a, c). In contrast, ANP did not affect calcium and shortening responses to ISO (Fig. 1b, d).

This disparity was further revealed in electrophysiological recordings of L-type $\mathrm{Ca}^{2+}$ currents. Currents through L-type $\mathrm{Ca}^{2+}$ channels were measured using the patch-clamp technique in the whole-cell configuration. Ang II $(10 \mathrm{nM})$ and ISO $(100 \mathrm{nM})$ both acutely amplified $\mathrm{Ca}^{2+}$ current densities (Fig. 2a-d). ANP (100 nM) alone did not affect L-type $\mathrm{Ca}^{2+}$ current densities (Fig. 2b, d). Pretreatment with ANP fully inhibited Ang II-stimulation of L-type $\mathrm{Ca}^{2+}$ channel activity (Fig. 2b) and had no effect on ISO-stimulation of L-type $\mathrm{Ca}^{2+}$ channel activity (Fig. 2d).

Taken together, these experiments demonstrate that ANP selectively inhibits the myocyte calcium responses to Ang II, but not to $\beta$-adrenergic stimulation.

The inhibitory effects of ANP on myocyte $\mathrm{Ca}^{2+}$ responses to Ang II are mediated by GC-A/ cGMP/PKG I-dependent modulation of RGS2

Next, we examined the receptor and post-receptor signalling cascade which mediates inhibitory effects of ANP on calcium responses to Ang II. First, to elucidate whether the GC-A receptor is involved, we compared effects of ANP on $\mathrm{Ca}^{2+}{ }_{\mathrm{i}}$ transients in isolated adult ventricular myocytes from mice with cardiomyocyte-restricted GC-A-deletion (CM GC-A KO) and respective control littermates. Myocyte diastolic and systolic $\mathrm{Ca}^{2+}{ }_{\mathrm{i}}$ levels and amplitudes of $\mathrm{Ca}^{2+}$ transients were not different between genotypes (Fig. 3a). Superfusion of myocytes with Ang II (10 nM) induced acute increases of free systolic $\mathrm{Ca}^{2+}{ }_{i}$ levels in both genotypes. ANP fully prevented the $\mathrm{Ca}^{2+}{ }_{\mathrm{i}}$ responses of control myocytes to Ang II. In contrast, the $\mathrm{Ca}^{2+}{ }_{\mathrm{i}}$ responses of GC-A-deficient myocytes to Ang II were not altered by ANP (Fig. 3a). We conclude that GC-A/cGMP signalling mediates the counteraction of myocyte $\mathrm{Ca}^{2+}$ responses to Ang II by ANP.

Several cGMP-modulated proteins are expressed in myocytes, such as phosphodiesterases (PDE 2, 3 and 9) and PKG I [47]. To investigate the possible contribution of PKG I, we took advantage of a genetic smooth muscle rescue mouse model that lacks expression of PKG I in cardiomyocytes (mouse genotype: PKG I ${ }^{\mathrm{L}-/ \mathrm{L}-} ; \mathrm{SM}-\mathrm{I} \beta^{+/-}$; $\mathrm{PKG} \mathrm{I}^{-1-}$ myocytes) [49]. As shown in Fig. 3b, basal $\mathrm{Ca}^{2+}{ }_{\mathrm{i}}$ transients and calcium responses to Ang II were in $\mathrm{PKG} \mathrm{I}^{-1-}$ like in respective control myocytes. However, while in respective control myocytes the stimulatory effects of Ang II were fully abolished in the presence of ANP, in PKG I ${ }^{-1-}$ myocytes ANP pretreatment could not prevent the calcium-stimulating effects of Ang II (Fig. 2b). Corroborating these findings, the inhibitory effects of ANP in control myocytes were completely prevented by the selective PKG I inhibitor Rp-8-Br-PET-cGMP $(10 \mu \mathrm{M}$, 
Fig. $1 \mathrm{Ca}^{2+}{ }_{\mathrm{i}}$ transients (Indo-1 ratio $_{405 / 495 \mathrm{~nm}}$, systolic-diastolic a, b) and simultaneously recorded cell length $\left(L_{\max }-L_{\min }\right.$, expressed as percent from $L_{\max }$ c, d) in field-stimulated myocytes at baseline and during superfusion with either Ang II $(10 \mathrm{nM})$ or ISO $(100 \mathrm{nM})$ in the presence or absence of ANP (100 nM, $10 \mathrm{~min}$ pretreatment). Top original tracings of $\mathrm{Ca}^{2+}{ }_{\mathrm{i}}$ transients. Bottom mean \pm SEM, $n=4-6$ cells from four mice; asterisks denote a significant difference versus basal (B) $(P<0.05)$
A
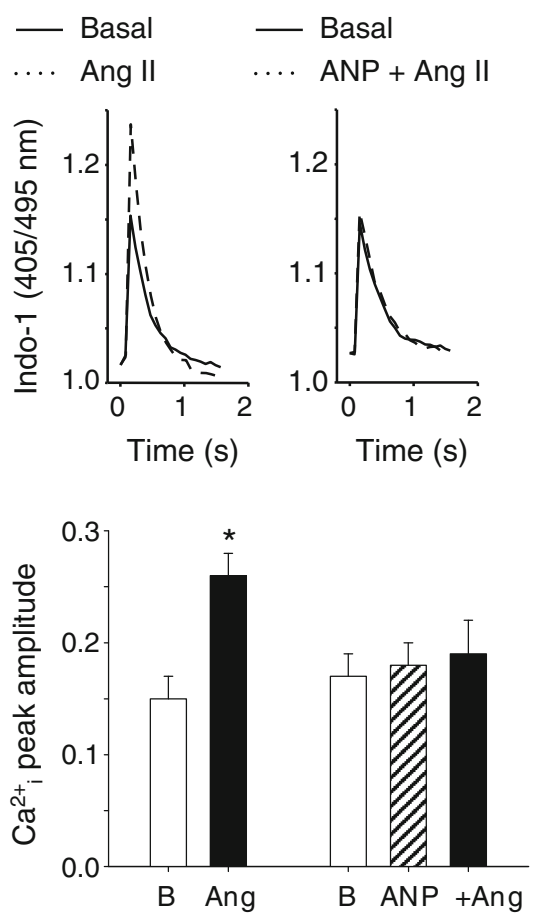

C

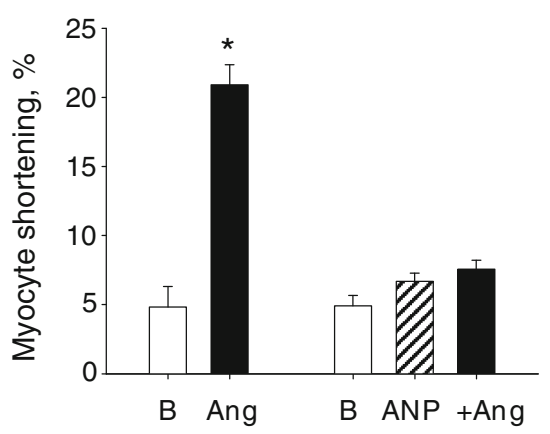

B
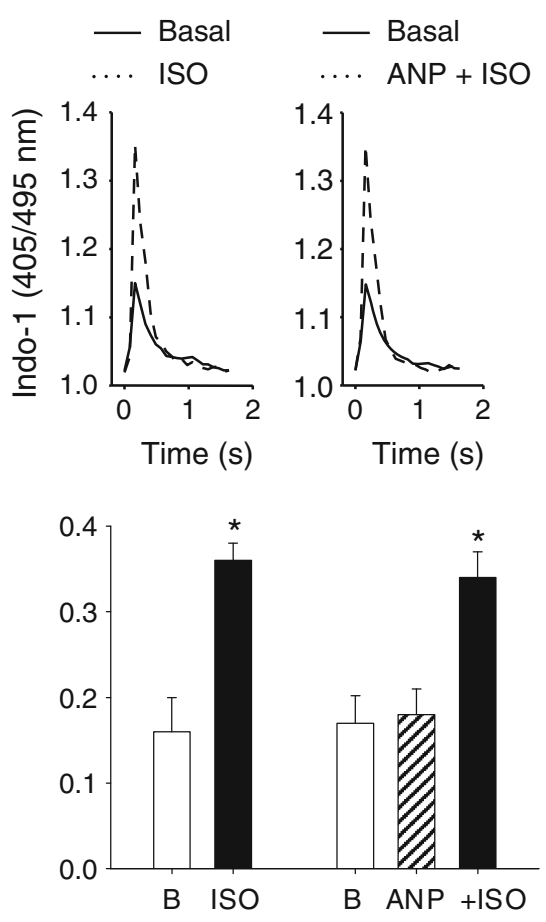

D

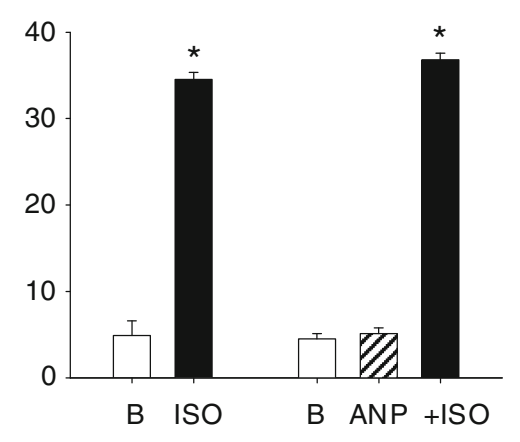

pretreatment for $30 \mathrm{~min}$ before addition of ANP and Ang II; Biolog, Hamburg, Germany), confirming PKG I-mediated effects (Fig. 3b).

Our observation that the ANP/GC-A/cGMP/PKG I pathway inhibits the myocyte $\mathrm{Ca}^{2+}$ responses to Ang II but not to ISO, seemed to indicate a selective modulation of $\mathrm{G}_{\alpha \mathrm{q} / 11}$-coupled receptor signalling. The regulator of $\mathrm{G}$ protein signalling (RGS)-2 is a selective and negative regulator of $\mathrm{G}_{\mathrm{q} / 11}$ proteins in the cardiovascular system which is activated by PKG I [51]. To study whether RGS2 mediates effects of ANP, we compared myocytes from RGS2-deficient mice and controls [15]. Because $10 \mathrm{nM}$ Ang II often provoked arrhythmias in RGS $2^{-1-}$ myocytes (not shown), instead we studied their responses to $1 \mathrm{nM}$ Ang II. As shown in Fig. 3c, the calcium responses of RGS 2-deficient myocytes to $1 \mathrm{nM}$ Ang II were greater as the responses of respective wild-type myocytes (controls) to $10 \mathrm{nM}$ Ang II. The calcium and shortening responses of
$\mathrm{RGS}^{-1-}$ myocytes to ISO were unaltered (not shown). Figure $3 \mathrm{c}$ also shows that the inhibitory effect of ANP on the calcium responses to Ang II was totally abolished in $\mathrm{RGS}^{-1-}$ myocytes.

Collectively, our findings are compatible with the notion that PKG I is the downstream target activated by the ANP/ GC-A/cGMP-signalling pathway in cardiac myocytes. cGMP/PKG I-mediated modulation of RGS2 and subsequent inhibition of $\mathrm{AT}_{1} / \mathrm{G} \alpha \mathrm{q}$ signalling appear to mediate the specific counter regulation of the calcium responses of myocytes to Ang II by ANP.

Activation of the ANP/GC-A/PKG I pathway in HEK293 enhances the expression and membrane localization of RGS2

To study whether the ANP/GC-A/PKG I system can modulate the expression or subcellular localization of 
Fig. 2 L-type $\mathrm{Ca}^{2+}$ channel activity was analyzed in ventricular myocytes by wholecell patch-clamp recordings. Left original L-type $\mathrm{Ca}^{2+}$ current traces of two cells at baseline and upon superfusion with $10 \mathrm{nM}$ Ang II (a) or $100 \mathrm{nM}$ ISO (c). Right change in L-type $\mathrm{Ca}^{2+}$ channel current density (I) in percent $\mathbf{b}$ after application of $10 \mathrm{nM}$ Ang II, $100 \mathrm{nM}$ ANP or ANP and Ang II ( $n=7$ cells from 3 mice $)$ and d after application of $100 \mathrm{nM}$ ISO, $100 \mathrm{nM}$ ANP or ANP and ISO ( $n=5$ cells from 3 mice); $* P<0.05$ versus $\mathrm{B}$, basal

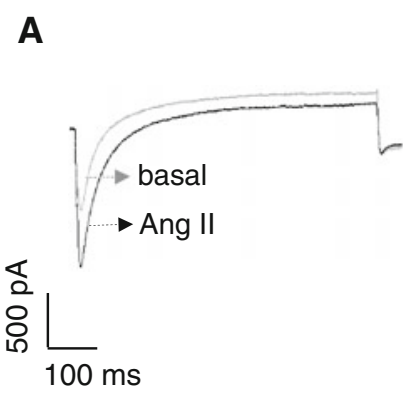

C

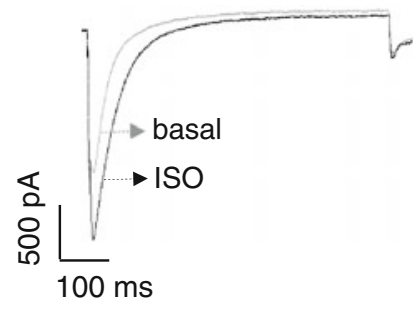

B

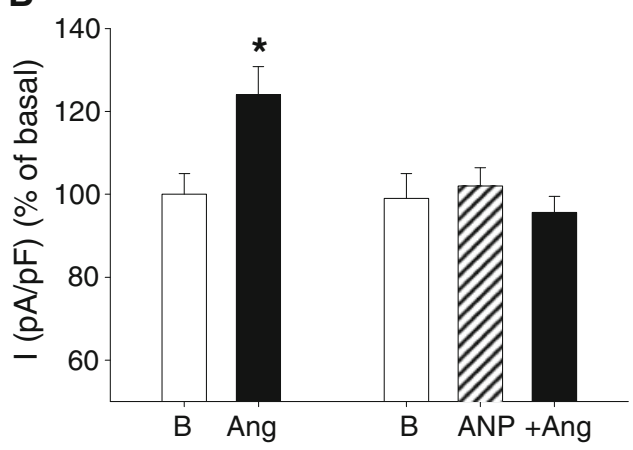

D

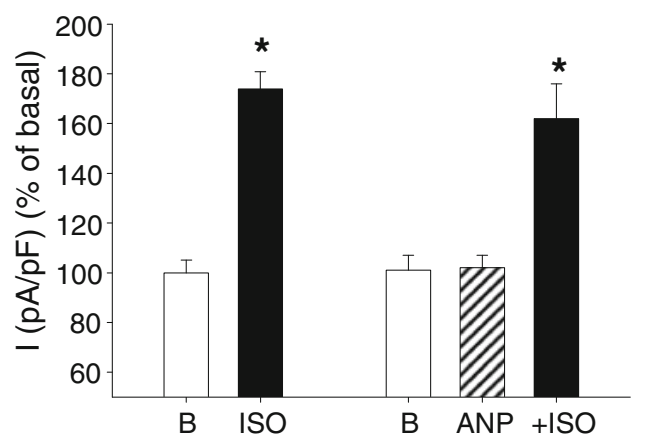

RGS2, we compared the relative amounts of RGS2 protein in cytoplasmic and membrane fractions of transfected HEK293 cells before and after PKG I activation by ANP. As shown in Fig. 4, ANP (10 nM, incubation for 30, 60 and $120 \mathrm{~min}$ ) caused a time-dependent increase in the total expression of RGS2 as well as in the amount of RGS2 associated with the plasma membrane. After $2 \mathrm{~h}$, the expression of RGS2 increased by 5.9-fold (in the cytosol) and 8.6-fold (at the plasma membrane) in ANP-treated when compared with untreated cells.

Mice with cardiomyocyte-restricted deletion of GC-A show exacerbated cardiac hypertrophy in response to Ang II, but not to ISO

To elucidate whether these selective interactions between ANP and Ang II, but not ISO signalling play a role in vivo, in intact hearts, we compared the cardiac hypertrophic responses of CM GC-A KO and respective control littermates [18] to exogenous Ang II or ISO administration. It should be emphasized that the cardiac effects are abolished whereas all systemic functions of ANP/GC-A are preserved in CM GC-A KO mice [18]. Ang II (250 ng/kg BW/min, 14 days) or ISO (40 mg/kg BW/day, 7 days [5]) were administered s.c. via osmotic minipumps. Unexpectedly, contrasting with many published studies [19 and others], in our hands this low, so-called "suppressor" Ang II dose provoked significant increases in arterial blood pressure (increases in systolic blood pressure levels by $\sim 30 \mathrm{~mm}$ $\mathrm{Hg}$; see Fig. 5a). Hypertensive reactions were similar in mice from both genotypes. In contrast, ISO essentially had no effect on blood pressure (Fig. 5a). In both genotypes, chronic administration of Ang II or of ISO led to significant cardiac hypertrophy, as demonstrated by the increases in the left ventricular (LV) weight - to - body weight (BW) ratios (Fig. 5b) and the enlargement of LV myocyte diameters (Fig. 5c). Notably, these effects of Ang II on cardiac remodeling were more pronounced in CM GC-A KO mice than in controls (Fig. 5b, c), despite the similar hypertensive reactions. In contrast, the hypertrophic effects of ISO were not different between genotypes (Fig. 5b, c). We conclude from these in vivo data that a chronic inhibition of the local, cardiac effects of ANP exacerbates the hypertrophic actions of Ang II, but not of $\beta$-adrenergic stimulation.

Enhanced Ang II-induced cardiac hypertrophy in CM GC-A KO mice is accompanied by greater activation of the $\mathrm{Ca}^{2+} /$ calmodulin-dependent kinase II pathway

Because increases in cytoplasmic $\mathrm{Ca}^{2+}$ can induce cardiomyocyte hypertrophy through $\mathrm{Ca}^{2+} /$ calmodulin-mediated activation of CaMKII signalling [30], we assessed the activity of this pathway. The cardiac left ventricular expression of total CaMKII was not different between genotypes and/or treatment groups (Fig. 6 top). However, 

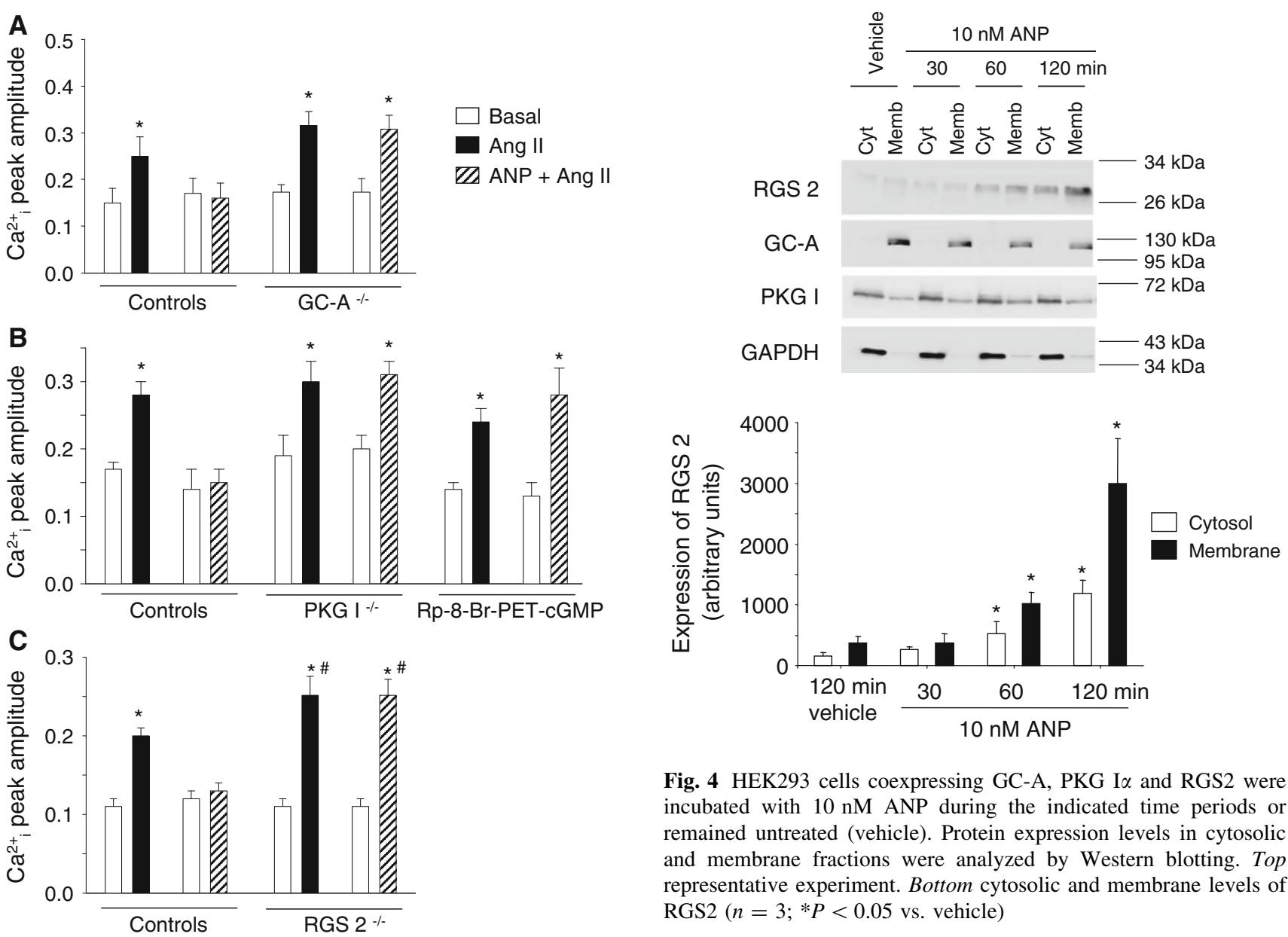

Fig. 4 HEK293 cells coexpressing GC-A, PKG I $\alpha$ and RGS2 were incubated with $10 \mathrm{nM}$ ANP during the indicated time periods or remained untreated (vehicle). Protein expression levels in cytosolic and membrane fractions were analyzed by Western blotting. Top representative experiment. Bottom cytosolic and membrane levels of RGS2 ( $n=3 ; * P<0.05$ vs. vehicle)

Fig. $3 \mathrm{Ca}^{2+}{ }_{i}$ transients (Indo-1 $\mathrm{ratio}_{405 / 495 \mathrm{~nm}}$, systolic-diastolic) in field-stimulated cardiomyocytes at baseline and during superfusion with Ang II in the presence or absence of ANP. In respective control cardiomyocytes (with unaltered protein expression levels) Ang II $(10 \mathrm{nM})$ increased systolic $\mathrm{Ca}^{2+}{ }_{\mathrm{i}}$ levels and the peak amplitude of $\mathrm{Ca}^{2+}{ }_{\mathrm{i}}$ transients. This $\mathrm{Ca}^{2+}{ }_{\mathrm{i}}$ responses to Ang II were fully prevented in the presence of ANP (100 $\mathrm{nM}$, pretreatment during $10 \mathrm{~min})$. This inhibitory effect of ANP on the $\mathrm{Ca}^{2+}{ }_{\mathrm{i}}$ responses to Ang II was abolished $\mathbf{a}$ in GC-A-deficient (GC-A ${ }^{-1-}$ ), $\mathbf{b}$ in PKG I-deficient (PKG $\mathrm{I}^{-/-}$) and $\mathbf{c}$ in RGS2-deficient (RGS2 ${ }^{-/-}$) myocytes. b The inhibitory effect of ANP on the responses to Ang II was also abolished after pharmacological blockade of PKG I with Rp-8-Br-PET-cGMP $\left(10 \mu \mathrm{M}, 30 \mathrm{~min}\right.$ pretreatment). c Note that in RGS2 ${ }^{-1-}$ myocytes the $\mathrm{Ca}^{2+}{ }_{\mathrm{i}}$-stimulating effects of Ang II $(1 \mathrm{nM})$ were significantly greater when compared with the effects of Ang II $(10 \mathrm{nM})$ on control cells; $n=4-6$ cells ( 4 mice per genotype); $* P<0.05$ versus basal; ${ }^{\#} P<0.05$ versus controls

the levels of autophosphorylated (active) CaMKII were increased in CM GC-A KO mice already under basal conditions (vehicle treatment; Fig. 6a, b). In control mice chronic Ang II or ISO treatment significantly increased cardiac CaMKII autophosphorylation. The effect of Ang II was markedly enhanced in CM GC-A KO mice (Fig. 6a). In contrast, ISO treatment did not further increase pCaMKII levels in hearts of CM GC-A KO mice (Fig. 6b).

TRPC3/C6 channels are involved in the calcium responses of adult cardiac myocytes to Ang II, but not to ISO

Although TRPC3 and TRPC6 channels have been implicated as essential elements mediating calcium and growth responses of neonatal cardiomyocytes to Ang II [34], their role in adult myocytes remained unexplored. To elucidate whether the $\mathrm{Ca}^{2+}{ }_{\mathrm{i}}$ responses of adult cardiomyocytes to Ang II are mediated by TRPC3/C6 activation, first, we studied the calcium responses to Ang II in adult cardiomyocytes from double $\mathrm{KO}$ mice with genetic deletion of both TRPC 3 and TRPC6 (TRPC $3^{-1-} / \mathrm{C6}^{-1-}$ ) $[3,11]$. As shown in Fig. $7 \mathrm{a}-\mathrm{d}$, the baseline $\mathrm{Ca}^{2+}{ }_{\mathrm{i}}$ transients of control and $\mathrm{TRPC}^{-1-} / \mathrm{C6}^{-1-}$ cardiomyocytes were similar. Basal $\mathrm{Ca}^{2+}$-current densities were also similar and amounted to $-6.06 \pm 0.61 \mathrm{pA} / \mathrm{pF}$ in control and to $-6.21 \pm 0.59 \mathrm{pA} /$ $\mathrm{pF}$ in TRPC $3^{-1-} / \mathrm{C}^{-1-}$ cardiomyocytes $(11$ cells from 2 animals per genotype). The stimulatory effects of Ang II $(10 \mathrm{nM})$ on $\mathrm{Ca}^{2+}{ }_{\mathrm{i}}$ transients (fluorometric measurements; Fig. 7a) and L-type $\mathrm{Ca}^{2+}$ currents (Fig. 8a, b) were completely absent in $\mathrm{TRPC}^{-1-} / \mathrm{C}^{-1-}$ cardiomyocytes. In contrast, the effects of ISO $(100 \mathrm{nM})$ on $\mathrm{Ca}^{2+}{ }_{\mathrm{i}}$ transients 
Fig. 5 Effect of chronic treatment with Ang II or ISO on a systolic blood pressure (SBP), b left ventricular weight (LVW) - to body weight (BW) ratios, and $\mathbf{c}$ myocyte diameters of floxed GC-A (controls) and CM GC-A KO mice; $(n=8-12$ per group) asterisks denote a significant difference versus vehicle $(P<0.05)$, crosses denote a significant difference from control mice $(P<0.05)$

Fig. 6 Effect of chronic Ang II (a) or ISO infusion (b) on the cardiac expression and autophosphorylation of CaMKII. Top representative Western blots for the left ventricular levels of autophosphorylated CaMKII, total CaMKII and GAPDH. Bottom levels of phosphorylated CaMKII were normalized to the total levels of CaMKII and calculated as $\mathrm{X}$-fold respective vehicle-treated control mice; $(n=8 ; * P<0.05$ when compared with vehicle; ${ }^{\#} P<0.05$ compared with controls)

CM GC-A KO mice

$\square$ Vehicle
Ang II
ISO

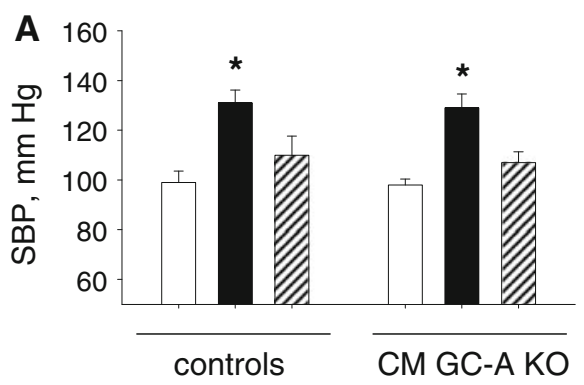

B

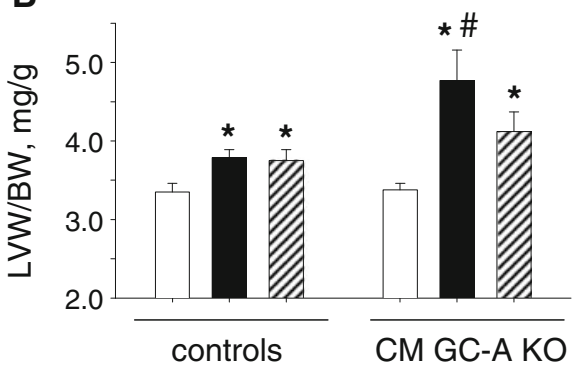

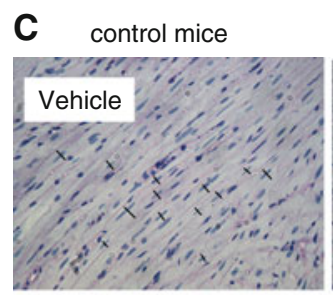
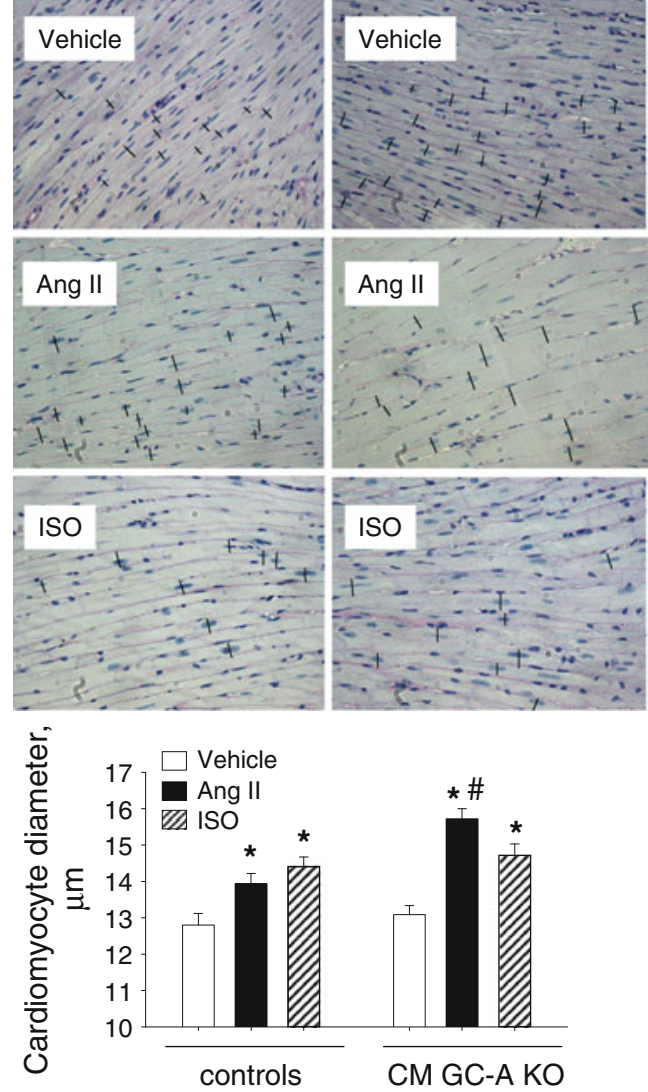

A

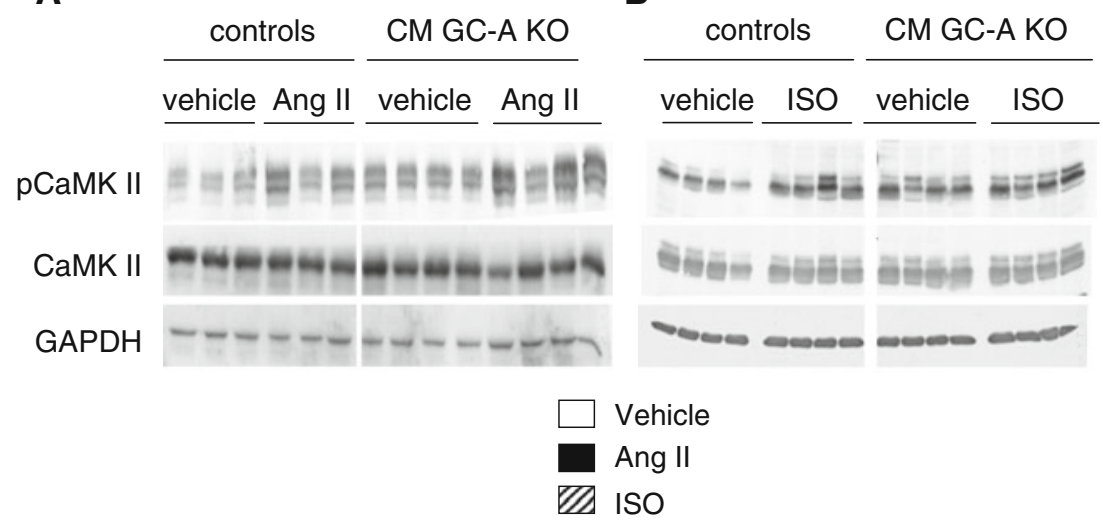

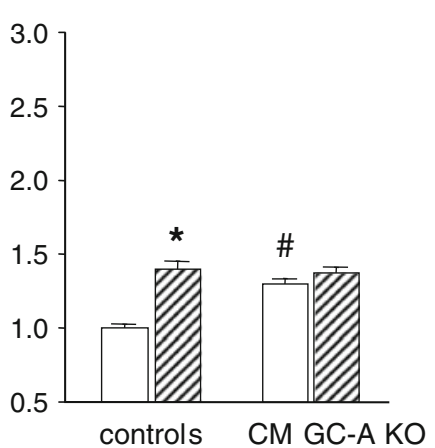


Fig. $7 \mathrm{Ca}^{2+}{ }_{\mathrm{i}}$ transients (Indo-1 ratio $_{405 / 495} \mathrm{~nm}$, systolicdiastolic) in field-stimulated cardiomyocytes at baseline and during superfusion with either Ang II or ISO. The stimulatory effects of Ang II were abolished in myocytes with genetic (TRPC $^{-l-} / \mathrm{C6}^{-1-}$ ) (a) or pharmacological inhibition of TRPC channels ( $2 \mu \mathrm{M}$ BTP 2 , pretreatment during $15 \mathrm{~min})(\mathbf{c})$. The effects of ISO were preserved (b, d). Asterisks denote a significant difference versus basal (B) $(P<0.05)$. For each condition, six cells from four mice were tested
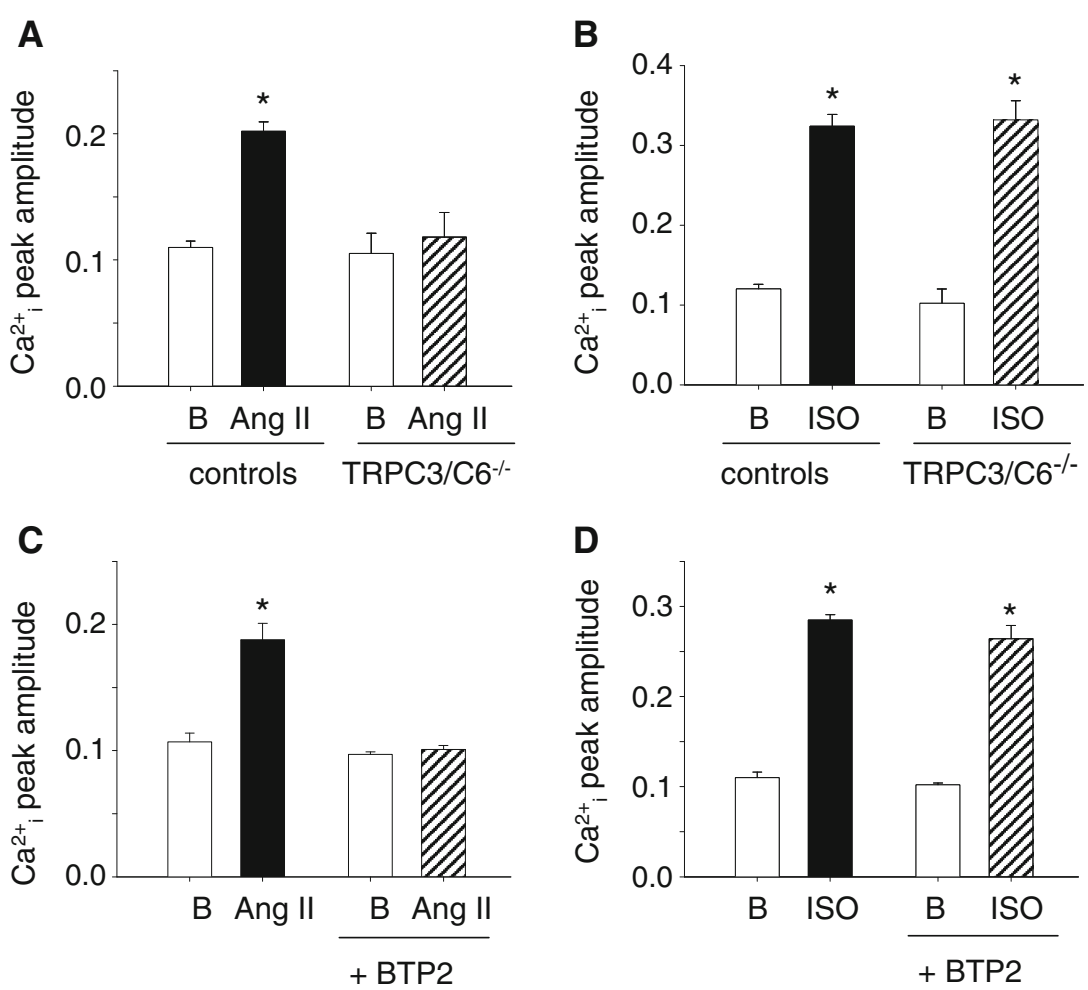

(Fig. 7b) and L-type $\mathrm{Ca}^{2+}$ currents (Fig. 8c, d) were not different between genotypes. Corroborating these observations, in control myocytes the inhibition of TRPC channel activity with the 3,5-bis(trifluoromethyl)pyrazole derivative, BTP2 (2 $\mu \mathrm{M}$; Calbiochem [13]), fully abolished the stimulatory effects of Ang II on $\mathrm{Ca}^{2+}{ }_{i}$ transients (Fig. 7c) and did not alter the effects of ISO (Fig. 7d).

\section{Discussion}

Major findings

The present studies in vivo and in isolated myocytes show essentially that the ANP/GC-A/cGMP pathway counter regulates cardiac Ang II, but not $\beta$-adrenergic stimulation of calcium handling, of the calcium-dependent prohypertrophic CaMKII pathway and of cardiac hypertrophy. The mechanism behind this differential regulation of the Ang II versus ISO responses by ANP involves PKG I and the regulator of G protein signalling (RGS) 2, a major target of PKG I, because the inhibitory effects of ANP on the $\mathrm{Ca}^{2+}{ }_{i}$ responses to Ang II were abolished in PKG I- or RGS2deficient myocytes. Supporting these findings, in transfected HEK293 cells ANP, via GC-A/PKG I, markedly induced the expression of RGS2 and its translocation to the plasma membrane. We conclude that ANP, via GC-A/cGMP/PKG I
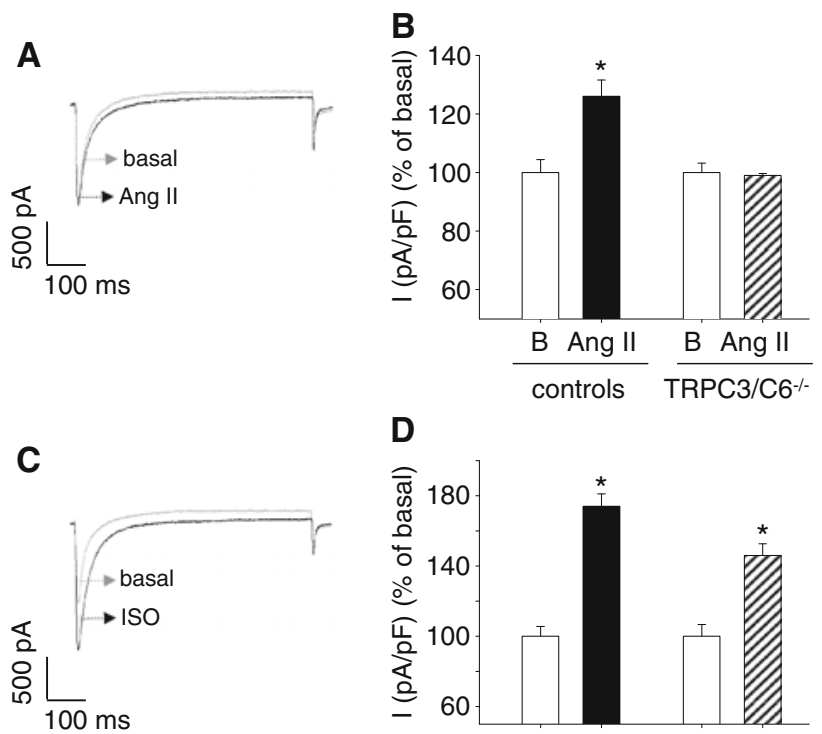

Fig. 8 Stimulation of L-type $\mathrm{Ca}^{2+}$ channel activity by Ang II and ISO in wild-type myocytes (controls) and myocytes from $\mathrm{TRPC}^{-1-}$, $\mathrm{C}^{-1-}$ mice. Left representative L-type $\mathrm{Ca}^{2+}$ current traces at baseline and upon superfusion either with $10 \mathrm{nM}$ Ang II (a) or with $100 \mathrm{nM}$ Iso (c). Right stimulation of L-type $\mathrm{Ca}^{2+}$ channel current density (I, in percent) in cells of wild-type (controls) or TRPC $3^{-1-} /$ TRPC $^{-/-}$ mice $\mathbf{b}$ after application of $10 \mathrm{nM}$ Ang II ( $n=6$ cells from 3 mice) and $\mathbf{d}$ after application of $100 \mathrm{nM}$ ISO $(n=5$ cells from 2 mice; $* P<0.05$ vs. basal, B) 
signalling and activation of RGS2, specifically counter regulates the hypertrophic effects of agonists linked to $\mathrm{G} \alpha \mathrm{q}$ protein coupled receptors, such as Ang II. In contrast, ANP does not affect $\beta$-adrenergic modulation of cardiac calcium handling and myocyte growth. Lastly, our study extents and strengthens previously published observations in neonatal cardiomyocytes [34] demonstrating for the first time that transient receptor potential canonical TRPC3/C6 channels are indispensable for the calcium responses of adult myocytes to Ang II and are not involved in calcium responses to $\beta$-adrenergic stimulation.

Differential regulation of cardiac Ang II, but not $\beta$-adrenergic responses by ANP

Our results are in accordance with previous studies showing that cardiac remodeling in mice with global (not cardiomyocyte specific) GC-A disruption is markedly inhibited by genetic or pharmacological blockade of the $\mathrm{AT}_{1}$ receptor [27]. As a corollary, Ang II-induced cardiac remodeling was suppressed in mice overexpressing brain natriuretic peptide (BNP) in the circulation, a member of the natriuretic peptide family which also activates the GC-A receptor, although with less affinity than ANP [43]. However, these studies could not distinguish between systemic and cardiac interactions of ANP/BNP and Ang II. Our study adds an important piece of information, because the conditional, cardiomyocyte-restricted disruption of the GC-A gene in mice allowed us to specifically dissect the local cardiac from the systemic interactions between the ANP/GC-A and Ang II/AT 1 systems. Furthermore, it characterizes PKG I and RGS2 as molecular effectors mediating the cross-talk between these pathways in cardiac remodeling.

Our observation of a differential regulation of Ang II- but not $\beta$-adrenergic stimulation of myocyte calcium handling by ANP is in agreement with a study by Takimoto et al. [44] which also observed that $\beta$-adrenergic calcium and contractile responses of adult myocytes and intact hearts are unaffected by ANP/GC-A-elicited cGMP production at the plasma membrane. In contrast, nitric oxide (NO)-stimulated cGMP production in the cytosol (which is mediated by the soluble guanylyl cyclase, sGC), markedly blunted the cardiac contractile responses to ISO [44, 50]. Extending these observations, cardiac overexpression of endothelial NO synthase in transgenic mice attenuated cardiac hypertrophy induced by chronic ISO infusion [36]. Hence, these studies indicate that the NO/sGC/cGMP system acts as a negative modulator of both the cardiac contractile and hypertrophic responses to $\beta$-adrenergic stimulation $[36,44]$. In contrast, the ANP/GC-A/cGMP system does not regulate these responses (present study and [44]). In conclusion, our observations support the notion that cGMP synthesized by sGC (in response to NO) and membrane-bound GC-A (in response to ANP) does not feed a common cGMP pool in cardiac myocytes, but instead remains spatially and functionally compartmentalized to modulate different targets and thereby different myocyte functions.

Counteraction of the cardiac Ang II effects by ANP/GC-A/cGMP involves PKG I and RGS2

At least two cGMP-stimulated proteins (as third messengers) are expressed in myocytes: PKG I; and phosphodiesterase (PDE) 2, a dual substrate esterase, which appears to hydrolyze cGMP under resting conditions [2], but targets cAMP in the presence of $\beta$-adrenergic stimulation [33]. In cultured endothelial cells, the ANP/GC-A/cGMP-signalling pathway stimulates PDE2 activity, decreases intracellular cAMP concentrations and thereby increases endothelial barrier functions [42]. However, in cardiomyocytes, the lack of effects of ANP on the calcium and inotropic responses to ISO (see present study and [44]) suggests that PDE 2 activity is not modulated by the pool of cGMP formed after ANP/GC-A stimulation. This could be due to spatial compartmentalization or could be related to different concentrations of cGMP reached after GC-A stimulation in myocytes (expressing low levels of GC-A) when compared with endothelia (with very dense GC-A expression) $[25,26]$.

Instead, using both a genetic and a pharmacological approach, our study demonstrates that PKG I is a downstream target activated by the ANP/GC-A/cGMP system in cardiomyocytes. As illustrated, the counter regulation of the $\mathrm{Ca}^{2+}$ responses of isolated adult myocytes to Ang II by ANP was absent in PKG I-deficient myocytes and also in wild-type myocytes pre-treated with the selective PKG I inhibitor, Rp-8-Br-PET-cGMP. However, the in vivo relevance of these in vitro findings has still to be demonstrated. Mice with a global deletion of PKG I show severe gastrointestinal dysfunction and high mortality before 6 weeks of age [38]. To circumvent these limitations, smooth muscle rescue mice were generated, in which PKG I expression is restored selectively in smooth muscle, but not in other cell types of PKG I null mice [49]. We used these rescue mice not only to isolate adult myocytes for our ex vivo calcium studies, but also to study the impact of PKG I deletion on the cardiac hypertrophic responses to chronic Ang II treatment. Ang II was administered for 14 days to eight 20 -week-old male PKG I rescue mice and eight litter-matched control mice (300 ng Ang II/kg BW/ min with osmotic minipumps). Interestingly, the cardiac hypertrophic responses to Ang II were attenuated in the PKG I mutants when compared with control mice (data not shown). However, it is important to note that this group 
of rescue mice also showed a systemic phenotype. Unfortunately, these animals had anemia and splenomegalia [7]. In addition, and in contrast to the normal blood pressure of 10-week-old PKG I rescue mice [49], we observed in the "older" rescue mice pronounced arterial hypotension (decreases in SBP by $\sim 20 \mathrm{mmHg}$ measured by the tail cuff method, both before and during Ang II administration, data not shown). Thus, it is likely that the attenuated hypertrophic response of the PKG I mutants to Ang II is related to their systemic phenotype, especially to arterial hypotension. Hence, although our own and published data support an important protective role for myocardial PKG I in pathological cardiac hypertrophy in vivo [45], a final proof is lacking.

At least in vitro several proteins centrally involved in myocyte calcium handling have been shown to be regulated by PKG I, such as the L-type $\mathrm{Ca}^{2+}$ channel (inhibition), phospholemman (inhibition) and phospholamban (inhibition, resulting in enhanced SR calcium uptake by SERCA) [6]. Our observation that the ANP/GC-A/cGMP/ PKG I pathway selectively inhibits the myocyte $\mathrm{Ca}^{2+}$ responses to Ang II, but not to ISO, suggested a selective modulation of $\mathrm{G}_{\alpha \mathrm{q} / 11^{-}}$-coupled receptor signalling. The regulator of $G$ protein signalling (RGS)-2 is a selective and negative regulator of $\mathrm{G}_{\mathrm{q} / 11}$ proteins in the cardiovascular system which is activated by PKG I [51]. For instance, in vascular smooth muscle cells the nitric oxide/ sGC/cGMP/PKG I pathway regulates the degradation of RGS2 and promotes its association with the plasma membrane by a mechanism requiring its PKG I phosphorylation sites [35]. By regulating RGS2 plasma membrane association and degradation, PKG I therefore may control its inhibitory effect on $\mathrm{Gq} / 11$-coupled receptors [35]. RGS2-deficient mice ( $\mathrm{RGS}^{-1-}$ ) are hypertensive, exhibit increased vasoconstrictory responses to vasopressin and other hormones activating $\mathrm{G}_{\mathrm{q} / 11}$-coupled receptors and diminished vasodilating responses to nitric oxide/ cGMP/PKG I signalling [14, 15, 35, 46]. Consistent with these observations, we found in the present study that the calcium responses of $\mathrm{RGS}^{-/-}$myocytes to Ang II were enhanced, whereas responses to $\beta$-adrenergic stimulation were unaltered. Notably, the inhibitory effect of ANP on calcium responses to Ang II was absent in $\mathrm{RGS}^{-1-}$ myocytes. Concomitantly, in transfected HEK293 cells ANP, via GC-A/PKG I signalling, dramatically enhanced RGS2 expression and membrane localization. We conclude from these experiments that ANP, via GC-A/cGMP/ PKG I, enhances the expression and/or phosphorylation of RGS2 and thereby counteracts AngII/AT1 signalling. In turn, inhibition of ANP/GC-A signalling (in CM GC-A $\mathrm{KO}$ mice) enhances the cardiac hypertrophic responses to Ang II. Unfortunately for technical reasons, we could not complement these experiments with analyses of RGS2 expression and/or phosphorylation in wild type when compared with GC-A- or PKG I-deficient myocytes. There are no phospho-specific antibodies available. Worse, Western-blot analyses revealed that commercially available anti-RGS2 antibodies unspecifically recognize an immunoreactive protein of $28 \mathrm{kDa}$ (the MW of RGS2) in tissues from both wild-type and RGS2-deficient mice (not shown). Hence, in our hands commercially available antibodies were unsuitable to study RGS2 expression in native tissues.

Collectively, our findings are compatible with the notion that PKG I is the downstream target activated by the ANP/ GC-A/cGMP-signalling pathway in cardiac myocytes. cGMP/PKG I-mediated modulation of RGS2 and subsequent inhibition of $\mathrm{AT}_{1} / \mathrm{Gq}$-signalling appear to mediate the specific counter regulation of the calcium responses of myocytes to Ang II by ANP.

TRPC3/C6 channels are involved in the calcium responses of adult myocytes to Ang II

Studies in neonatal rat cardiomyocytes have indicated that Ang II induces TRPC3/C6 activation through G $\alpha$ q-phospholipase C (PLC) signalling pathways [34]. DAG, generated by PLC activation, directly activates TRPC3/C6 [17]. In neonatal myocytes, this causes slow depolarization of the membrane potential and concomitantly increases the frequency of spontaneous firing due to activation of L-type $\mathrm{Ca}^{2+}$ channel [34]. Indeed, in our study with adult murine ventricular myocytes, the effects of Ang II both on $\mathrm{Ca}^{2+}$ transients and on L-type $\mathrm{Ca}^{2+}$ currents were abolished in TRPC3/C6-deficient myocytes. In addition, BTP2, which inhibits the activity of TRPC channels [13], abolished the calcium responses to Ang II. Taken together these experiments demonstrate that TRPC channels are indispensable for the calcium responses of adult ventricular myocytes to Ang II. In contrast, $\beta$-adrenergic stimulation of $\mathrm{Ca}^{2+}$ currents and $\mathrm{Ca}^{2+}{ }_{\mathrm{i}}$ handling was not altered by genetic or pharmacological blockade of TRPC channels. However, intriguingly, in whole-cell current-clamp recordings, we did not observe differences in the resting membrane potential of wild-type and TRPC3/C6-deficient myocytes or changes of the membrane potential in response to Ang II (data not shown). These unexpected findings point towards a novel mechanism of TRPC3/C6 activity regulating L-type $\mathrm{Ca}^{2+}$ channel (LTCC) activity in response to Ang II which we will try to elucidate in our future studies. One hypothesis is that TRPC-mediated $\mathrm{Ca}^{2+}$ entry activates CaMKII, which has been shown to be associated with cardiac LTCC complexes and increases channel open probability to dynamically increase $\mathrm{Ca}^{2+}$ current by a process called facilitation [10]. 


\section{Conclusion}

Patients with cardiac hypertrophy and/or congestive heart failure have elevated plasma levels of ANP and BNP [25, 26]. However, the cardiovascular and cGMP responses to these hormones are markedly attenuated, indicating impaired receptor or post-receptor responsiveness of GC-A $[25,26]$. Concurrently, the deleterious role of the local renin-angiotensin-aldosterone system in cardiac remodeling has been demonstrated by many experimental and clinical reports. Our study emphasizes that a disturbance of the delicate systemic and also local, cardiac balance between the ANP and RAA systems can critically contribute to the progression of cardiac hypertrophy.

Acknowledgments This study was supported by the Deutsche Forschungsgemeinschaft (SFB 487 to Michaela Kuhn). HEK293 cells stably expressing rat GC-A were generously provided by Dr. RueyBing Yang, Academia Sinica, Taipei, Taiwan. The plasmids for expression of human RGS2 and PKG I $\alpha$ were kindly provided by Dr. Thomas Wieland (Institute of Pharmacology, University of Mannheim-Heidelberg, Germany) and Dr. Stepan Gambaryan (Department of Clinical Biochemistry, University of Würzburg, Germany), respectively.

Author contributions Michael Klaiber performed and evaluated the fluorometric calcium measurements, western blotting, and heart morphometry. Martin Kruse performed and evaluated the electrophysiological calcium measurements. Katharina Völker performed the isolation of myocytes and in vivo studies. Juliane Schröter provided some technical help with the western blot analyses. Drs. Robert, Susanne Feil and Gerling generated and provided the PKG I deficient ("rescue") mice and anti-PKG I antibody. Drs. Freichel, Dietrich, Camacho Londoño, Joel Abramowitz, and Lutz Birnbaumer generated or provided the TRPC3/C6 knockout mice. The generation of these mice was supported by the Intramural Research Program of the NIH (Z01-ES101684 to JA and LB). Dr. Baba prepared the cardiac tissues for histology. Dr. Penninger provided RGS2 knockout mice. Michaela Kuhn conceived of and directed the study, analyzed the data, and wrote the manuscript, having helpful discussions with Dr. Pongs.

Open Access This article is distributed under the terms of the Creative Commons Attribution Noncommercial License which permits any noncommercial use, distribution, and reproduction in any medium, provided the original author(s) and source are credited.

\section{References}

1. Bers DM (2008) Calcium cycling and signaling in cardiac myocytes. Annu Rev Physiol 70:23-49 Review

2. Castro LR, Verde I, Cooper DM, Fischmeister R (2006) Cyclic guanosine monophosphate compartmentation in rat cardiac myocytes. Circulation 113:2221-2228

3. Dietrich A, Mederos Y, Schnitzler M, Gollasch M, Gross V, Storch U, Dubrovska G, Obst M, Yildirim E, Salanova B, Kalwa H, Essin K, Pinkenburg O, Luft FC, Gudermann T, Birnbaumer L (2005) Increased vascular smooth muscle contractility in TRPC6-/- mice. Mol Cell Biol 25:6980-6989
4. Diniz GP, Carneiro-Ramos MS, Barreto-Chaves ML (2009) Angiotensin type 1 receptor mediates thyroid hormone-induced cardiomyocyte hypertrophy through the Akt/GSK-3beta/mTOR signaling pathway. Basic Res Cardiol 104:653-667

5. Errami M, Galindo CL, Tassa AT, Dimaio JM, Hill JA, Garner HR (2008) Doxycycline attenuates isoproterenol- and transverse aortic banding-induced cardiac hypertrophy in mice. J Pharmacol Exp Ther 324:1196-1203

6. Feil R, Lohmann SM, de Jonge H, Walter U, Hofmann F (2003) Cyclic GMP-dependent protein kinases and the cardiovascular system: insights from genetically modified mice. Circ Res 93:907-916

7. Föller M, Feil S, Ghoreschi K, Koka S, Gerling A, Thunemann M, Hofmann F, Schuler B, Vogel J, Pichler B, Kasinathan RS, Nicolay JP, Huber SM, Lang F, Feil R (2008) Anemia and splenomegaly in cGKI-deficient mice. Proc Natl Acad Sci USA A105:6771-6776

8. Frey N, Mc Kinsey TA, Olson EN (2000) Decoding calcium signals involved in cardiac growth and function. Nat Med 6:1221-1227

9. Fujisaki H, Ito H, Hirata Y, Tanaka M, Hata M, Lin M, Adachi S, Akimoto H, Marumo F, Hiroe M (1995) Natriuretic peptides inhibit angiotensin II-induced proliferation of rat cardiac fibroblasts by blocking endothelin-1 gene expression. J Clin Invest 96:1059-1065

10. Grueter CE, Abiria SA, Dzhura I, Wu Y, Ham AJ, Mohler PJ, Anderson ME, Colbran RJ (2006) L-type $\mathrm{Ca}^{2+}$ channel facilitation mediated by phosphorylation of the beta subunit by CaMKII. Mol Cell 23:641-650

11. Hartmann J, Dragicevic E, Adelsberger H, Henning HA, Sumser M, Abramowitz J, Blum R, Dietrich A, Freichel M, Flockerzi V, Birnbaumer L, Konnerth A (2008) TRPC3 channels are required for synaptic transmission and motor coordination. Neuron 59:392-398

12. Hartmann M, Skryabin BV, Müller T, Gazinski A, Schröter J, Gassner B, Nikolaev VO, Bünemann M, Kuhn M (2008) Alternative splicing of the guanylyl cyclase-A receptor modulates atrial natriuretic peptide signaling. J Biol Chem 283:28313-28320

13. He LP, Hewavitharana T, Soboloff J, Spassova MA, Gill DL (2005) A functional link between store-operated and TRPC channels revealed by the 3, 5-bis(trifluoromethyl)pyrazole derivative, BTP2. J Biol Chem 280:10997-11006

14. Hercule HC, Tank J, Plehm R, Wellner M, da Costa Goncalves AC, Gollasch M, Diedrich A, Jordan J, Luft FC, Gross V (2007) Regulator of $\mathrm{G}$ protein signalling 2 ameliorates angiotensin IIinduced hypertension in mice. Exp Physiol 92:1014-1022

15. Heximer SP, Knutsen RH, Sun X, Kaltenbronn KM, Rhee MH, Peng N, Oliveira-dos-Santos A, Penninger JM, Muslin AJ, Steinberg TH, Wyss JM, Mecham RP, Blumer KJ (2003) Hypertension and prolonged vasoconstrictor signaling in RGS2deficient mice. J Clin Invest 111:445-452

16. Hill JA, Olson EN (2008) Cardiac plasticity. N Engl J Med 358:1370-1380

17. Hofmann T, Obukhov AG, Schaefer M, Harteneck C, Gudermann T, Schultz G (1999) Direct activation of human TRPC6 and TRPC3 channels by diacylglycerol. Nature 397:259-263

18. Holtwick R, van Eickels M, Skryabin BV, Baba HA, Bubikat A, Begrow F, Schneider MD, Garbers DL, Kuhn M (2003) Pressureindependent cardiac hypertrophy in mice with cardiomyocyterestricted inactivation of the atrial natriuretic peptide receptor guanylyl cyclase-A. J Clin Invest 111:1399-1407

19. Katahira K, Mikami H, Ogihara T, Kohara K, Otsuka A, Kumahara Y, Khosla MC (1989) Synergism of intraventricular $\mathrm{NaCl}$ infusion and suppressor angiotensins in rats. Am J Physiol 256:H1-H8

20. Kilic A, Velic A, De Windt LJ, Fabritz L, Voss M, Mitko D, Zwiener M, Baba HA, van Eickels M, Schlatter E, Kuhn M 
(2005) Enhanced activity of the myocardial $\mathrm{Na}^{+} / \mathrm{H}^{+}$exchanger NHE-1 contributes to cardiac remodeling in atrial natriuretic peptide receptor-deficient mice. Circulation 112:2307-2311

21. Kim S, Iwao H (2000) Molecular and cellular mechanisms of angiotensin II-mediated cardiovascular and renal diseases. Pharmacol Rev 52:11-34

22. Kleinert HD, Maack T, Atlas SA, Januszewicz A, Sealey JE, Laragh JH (1984) Atrial natriuretic factor inhibits angiotensin-, norepinephrine-, and potassium-induced vascular contractility. Hypertension 6:I143-I147

23. Knowles JW, Esposito G, Mao L, Hagaman JR, Fox JE, Smithies O, Rockman HA, Maeda N (2001) Pressure-independent enhancement of cardiac hypertrophy in natriuretic peptide receptor A-deficient mice. J Clin Invest 107:975-984

24. Kruse M, Schulze-Bahr E, Corfield V, Beckmann A, Stallmeyer B, Kurtbay G, Ohmert I, Schulze-Bahr E, Brink P, Pongs O (2009) Impaired endocytosis of the ion channel TRPM4 is associated with human progressive familial heart block type I. J Clin Invest 119:2737-2744

25. Kuhn M (2004) Molecular physiology of natriuretic peptide signalling. Basic Res Cardiol 99:76-8226

26. Kuhn M (2009) Function and dysfunction of mammalian membrane guanylyl cyclase receptors: lessons from genetic mouse models and implications for human diseases. Handb Exp Pharmacol. 191:47-69

27. Li Y, Kishimoto I, Saito Y, Harada M, Kuwahara K, Izumi T, Takahashi N, Kawakami R, Tanimoto K, Nakagawa Y, Nakanishi M, Adachi Y, Garbers DL, Fukamizu A, Nakao K (2002) Guanylyl cyclase-A inhibits angiotensin II type $1 \mathrm{~A}$ receptor-mediated cardiac remodeling, an endogenous protective mechanism in the heart. Circulation 106:1722-1728

28. Lopez MJ, Wong SK, Kishimoto I, Dubois S, Mach V, Friesen J, Garbers DL, Beuve A (1995) Salt-resistant hypertension in mice lacking the guanylyl cyclase-A receptor for atrial natriuretic peptide. Nature 378:65-68

29. Maack T, Marion DN, Carnargo MJ, Kleinert HD, Laragh JH, Vaughan ED, Atlas SA (1984) Effects of auriculin (atrial natriuretic factor) on blood pressure, renal function, and the reninaldosterone system in dogs. Am J Med 77:1069-1075

30. Maier LS (2009) Role of CaMKII for signaling and regulation in the heart. Front Biosci 14:486-496

31. Martin FL, Stevens TL, Cataliotti A, Schirger JA, Borgeson DD, Redfield MM, Luchner A, Burnett JC Jr (2005) Natriuretic and antialdosterone actions of chronic oral NEP inhibition during progressive congestive heart failure. Kidney Int 67:1723-1730

32. Mazzolai L, Nussberger J, Aubert J-H, Brunner DB, Gabbiani G, Brunne HR, Pedrazzini T (1998) Blood pressure-independent cardiac hypertrophy induced by locally activated renin-angiotensin system. Hypertension 31:1324-1330

33. Mongillo M, Tocchetti CG, Terrin A, Lissandron V, Cheung YF, Dostmann WR, Pozzan T, Kass DA, Paolocci N, Houslay MD, Zaccolo M (2006) Compartmentalized phosphodiesterase-2 activity blunts beta-adrenergic cardiac inotropy via an $\mathrm{NO} /$ cGMP-dependent pathway. Circ Res 98:226-234

34. Onohara N, Nishida M, Inoue R, Kobayashi H, Sumimoto H, Sato Y, Mori Y, Nagao T, Kurose H (2006) TRPC3 and TRPC6 are essential for angiotensin II-induced cardiac hypertrophy. EMBO J 25:5305-5316

35. Osei-Owusu P, Sun X, Drenan RM, Steinberg TH, Blumer KJ (2007) Regulation of RGS2 and second messenger signaling in vascular smooth muscle cells by cGMP-dependent protein kinase. J Biol Chem 282:31656-31665

36. Ozaki M, Kawashima S, Yamashita T, Hirase T, Ohashi Y, Inoue N, Hirata K, Yokoyama M (2002) Overexpression of endothelial nitric oxide synthase attenuates cardiac hypertrophy induced by chronic isoproterenol infusion. Circ J 66:851-856
37. Paradis P, Dali-Youcef N, Paradis FW, Thibault G, Nemer M (2000) Overexpression of angiotensin II type I receptor in cardiomyocytes induces cardiac hypertrophy and remodeling. Proc Natl Acad Sci USA 97:931-936

38. Pfeifer A, Klatt P, Massberg S, Ny L, Sausbier M, Hirneiss C, Wang GX, Korth M, Aszodi A, Andersson KE, Krombach F, Mayerhofer A, Ruth P, Fassler R, Hofmann F (1998) Defective smooth muscle regulation in cGMP kinase I-deficient mice. EMBO J 17:3045-3051

39. Sadoshima J, Izumo S (1993) Molecular characterization of angiotensin II-induced hypertrophy of cardiac myocytes and hyperplasia of cardiac fibroblasts: critical role of the AT1 receptor subtype. Circ Res 73:413-423

40. Saygili E, Rana OR, Meyer C, Gemein C, Andrzejewski MG, Ludwig A, Weber C, Schotten U, Krüttgen A, Weis J, Schwinger RH, Mischke K, Rassaf T, Kelm M, Schauerte P (2009) The angiotensin-calcineurin-NFAT pathway mediates stretchinduced up-regulation of matrix metalloproteinases-2/-9 in atrial myocytes. Basic Res Cardiol 104:435-448

41. Seth M, Zhang ZS, Mao L, Graham V, Burch J, Stiber J, Tsiokas L, Winn M, Abramowitz J, Rockman HA, Birnbaumer L, Rosenberg P (2009) TRPC1 channels are critical for hypertrophic signaling in the heart. Circ Res 105:1023-1030

42. Surapisitchat J, Jeon KI, Yan C, Beavo JA (2007) Differential regulation of endothelial cell permeability by cGMP via phosphodiesterases 2 and 3. Circ Res 101:811-818

43. Takahahsi N, Saito Y, Kuwahara K, Harada M, Kishimoto I, Ogawa Y, Kawakami R, Nakagawa Y, Nakanishi M, Nakao K (2003) Angiotensin II-induced ventricular hypertrophy and extracellular signal-regulated kinase activation are suppressed in mice overexpressing brain natriuretic peptide in the circulation. Hypertens Res 26:847-853

44. Takimoto E, Belardi D, Tocchetti CG, Vahebi S, Cormaci G, Ketner EA, Moens AL, Champion HC, Kass DA (2007) Compartmentalization of cardiac beta-adrenergic inotropy modulation by phosphodiesterase type 5. Circulation 115:2159-2167

45. Takimoto E, Koitabashi N, Hsu S, Ketner EA, Zhang M, Nagayama T, Bedja D, Gabrielson KL, Blanton R, Siderovski DP, Mendelsohn ME, Kass DA (2009) Regulator of G protein signaling 2 mediates cardiac compensation to pressure overload and antihypertrophic effects of PDE5 inhibition in mice. J Clin Invest 119:408-420

46. Tang KM, Wang GR, Lu P, Karas RH, Aronovitz M, Heximer SP, Kaltenbronn KM, Blumer KJ, Siderovski DP, Zhu Y, Mendelsohn ME (2003) Regulator of G-protein signaling-2 mediates vascular smooth muscle relaxation and blood pressure. Nat Med 9:1506-1512

47. Tsai EJ, Kass DA (2009) Cyclic GMP signaling in cardiovascular pathophysiology and therapeutics. Pharmacol Ther 122:216-238

48. Valtcheva N, Nestorov P, Beck A, Russwurm M, Hillenbrand M, Weinmeister P, Feil R (2009) The commonly used cGMPdependent protein kinase type I (cGKI) inhibitor Rp-8-Br-PETcGMPS can activate cGKI in vitro and in intact cells. J Biol Chem 284:556-562

49. Weber S, Bernhard D, Lukowski R, Weinmeister P, Wörner R, Wegener JW, Valtcheva N, Feil S, Schlossmann J, Hofmann F, Feil R (2007) Rescue of cGMP kinase I knockout mice by smooth muscle specific expression of either isozyme. Circ Res 101:10961103

50. Westermann D, Riad A, Richter U, Jäger S, Savvatis K, Schuchardt M, Bergmann N, Tölle M, Nagorsen D, Gotthardt M, Schultheiss HP, Tschöpe C (2009) Enhancement of the endothelial NO synthase attenuates experimental diastolic heart failure. Basic Res Cardiol 104:499-509

51. Xie GX, Palmer PP (2007) How regulators of G protein signaling achieve selective regulation. J Mol Biol 366:349-365 